ZESZYTY NAUKOWE UNIWERSYTETU SZCZECIŃSKIEGO

NR 884

EKONOMICZNE PROBLEMY USŁUG NR 119

2015

DOI: 10.18276/epu.2015.119-11

\author{
Sergey Solodovnikov* \\ Olga Mazurenko**
}

\title{
THE EMPLOYMENT PROSPECTS AND THE DEVELOPMENT \\ OF THE SCIENTIFIC COMMUNITY \\ IN THE CONTEXT OF THE MODERNIZATION \\ OF THE BELARUSIAN ECONOMY
}

\begin{abstract}
The main principles of the creation of the social and scientific association while modernizing economy of the Republic of Belarus have been determined on the basis of the post-industrialization concept. They are the following: the principle of parallelism of the technical and technological modernization of economy and formation of postindustrial labor relations; the principle of labor-saving on the basis of the high technological industry; the principle of strategic orientation on the global technological tendencies; the principle of long life education of specialists; the principle of state promotion of scientific achievements into production; the principle of the growing influence of moral and ecological priorities. The necessity of forming effective information economy for creating social and scientific association has been demonstrated.
\end{abstract}

* Sergey Solodovnikov, Doctor of Economics, Full Professor, Belarus National Technical University, Faculty of Technologies of Management and Humanitarization, e-mail address: solodovnicov_s@tut.by.

** Olga Mazurenko, Master of Economics, postgraduate student, Belarus National Technical University, Faculty of Technologies of Management and Humanitarization, e-mail address: olga. maksimovna@inbox.ru. 
Keywords: technical and technological modernization, post-industrialization, modernization of the transitive economy

\section{Introduction}

The existence and development of human society ensure its material base is possible only on the basis of labor. The purpose of social production is not simply the production of wealth on the basis of the achieved level of technology development, but its production in the most economical way. This requires the full use of subjects' production capacity, which, in turn, translates itself into the consideration of interests of individuals and various social communities so as to organize and engage them in the most effective way in social production. This requires the co-existence of various forms of organizational-administrative division of labor in accordance with the specific historical and social conditions, even on the basis of an identical technological base of production.

In our opinion, labor relations act as a basis for social differentiation, political and economic dynamics of society. This statement is justified for the following reasons: firstly, genetically (historically) the labor relations are the basis for differentiation of individuals as the carrier of specific labor functions, and, on this basis, there occurs their differentiation as owners. Nevertheless, without losing sight of those important considerations, we should not forget that in societies with the developed socio-class differentiation, engaging individuals by certain types of work can be simply explained by their belonging into different property owners groups. Although, with the correct genetic approach, the problem remains the same, as the place of subjects in the property structure is it a derivative of the employment relationship. Moreover, when labor (production) interests determine economic system (Solodovnikov 2002: 781-782), individuals are endowed with the prerogatives of the owners (or they are owners) precisely to the extent that it is necessary for carrying out certain labor functions. Secondly, historical experience shows that if the class of owners cannot fully (sometimes partially) carry out some socially important labor functions, it must either perish (along with the annihilation of the nation-state), or bring to the implementation of this socially important functions the representatives of other socio-class formations, giving the then de facto (and often de jure) partially or completely their prerogatives of 
owners. There is a vast number of examples of such a process in history (Solodovnikov 2003: 515).

\section{Trends and prospects for the employment development and the creation of the socio-science community under the condition of modernization of the Belorussian economy}

Today it has become clear that the innovative development of the Belorussian economy is possible only on the basis of a more rational use of labor resources. The reason for this is the inability to significantly increase Belorussian labor resources by attraction of foreign labor force. Belarus could (and, in our opinion, it should) attract up to two million foreign workers (naturally from the close cultural regions on an ongoing basis, in advance to determine the mechanisms of people attraction from different ethnic and regional groups, etc.) not only without the threat to national security, but also a great social and economic benefit. But for various reasons this is not done. So at the moment there is a necessity to mainly focus on its internal human reserves.

First of all, it should be clearly understood that the development of recommendations for the interested in them state bodies in the field of labor markets requires prior clarification: to what society we should strive for, and what kind of economy of the future society is the most adequate.

In our opinion, the Belorussian society will soon have to move into the postindustrial stage of development, and this will require the creation of a modern (post-industrial) labor relationship. It should be borne in mind that, according to the views of the founder of the post-industrial approach, D. Bell Bell (1973), the transition to a post-industrial economy does not mean the disappearance of agricultural and industrial structures, but the preservation of them both as dominant and peripheral. The post-industrial structure becomes dominant. The result is the enhanced complexity of the socio-economic processes.

The literature states that the methodological principles of the concept of post-industrialism were laid by K. Clark and J. Fourastié in the late 1930s - mid1940s. According to their views, "there are triad of sectors stand in social production (primary - agriculture, secondary - industry and tertiary - services). The transition from one sector to another, in their view, is feasible due, firstly, economic development, leading to relative changes in demand for the products of the 
sectors, and secondly, growth of productivity, reflected in the relative changes in the demand for labor in different sectors. Over time, tertiary sector becomes the dominant - both in terms of the share of employed people in total employment, and with the position of the share of production in this sector in the GDP" (Veredyuk 2010: 36).

In the works of later writers, there is an emphasis on the qualitative characteristics of the post-industrial society, which has led to the emergence of the concepts such as "information society" (Machlup 962); "Knowledge Society"; "technotronic society" (Brzezinski 1970); "network society" (Castells 1996); "environmental post-industrialism" (Roszak 1972). Since the inception of the concept of the post-industrial society characterized by the globality of methodological principles and scope of the problems covered such a concept can no longer be clearly assigned to either an economic, or a sociological, or a political science (Inozemtsev 1998).

The emergence and development of the post-industrial society is accompanied by, firstly, the changing nature of manufacturing, from mass production to flexible, technological innovation-oriented production, secondly, by the transition of the role of the locomotive of economy from industry to the services sector and, thirdly, a significant increase in the value of knowledge for the economic development.

The modern scientists - advocates of post-industrial areas, have begun to pay their attention to the mechanisms of producing the post-industrial society. As Veredyuk noted, "In studies of post-industrial trends in general can be found the vector splitting and detailing the post-industrial perspective. The leading domestic (Russian) scientific experts of postindustrialism include Inozemtsev V, Buzgalin A, Kolganova A, Medvedev V, Nureyev R. Their work not only address the research methodology of post-industrial society, the problems of the Russian economy to adapt to the new conditions as a whole, but also pay attention to the problems of the employment relationship. Among domestic (Russian) scientists whose research directly related to employment and labor market are Aghabekian R., Gimpelson V, Kapelyushnikov R" (Veredyuk 2010: 37).

Since it is only the transition of the Republic of Belarus to the postindustrial society that will ensure the standard of living as adopted today in Old Europe, it is necessary to offer the Belorussian government all but simple recommendations for optimization processes in the field of employment on the basis of the existing structure of the national economy (any other way the country will never be 
able to break the deadlock, "catch-up" development). There is also the need to develop the recommendations for the regulation of labor relations promoting the earlier post-industrial modernization of the country. In developing these recommendations we must be aware that there cannot first be created a post-industrial economy and then formed its adequate employment structure. Nor can there first be obtained the post-industrial vocational structure only for us to move quickly to the post-industrial stage of development with this human capacity. Carrying out the technical and technological modernization, creating the competitive (postindustrial) structure of the economy and building the modern (post-industrial) employment relationship should occur at the same time.

Here appears a temporary mismatch, or a temporal paradox, which is to ensure that the technical and technological re-equipment could be done within three years, while the training of people with the relevant (postindustrial) skills can take from 3 to 15 years (depending on the specific qualification and professional requirements, and performing certain professional duties). Below we will try to give our vision of a possible resolution of this contradiction.

The theoretical understanding of optimization processes in the field of employment under the conditions of transition of the Republic of Belarus to a postindustrial society causes a new (system) point of view both on the very category of employment and trends in the evolution of labor relations under the conditions of radical changes in the nature of industrial production (from mass production to flexible, technological innovation-oriented production) as well as the significant increase both in the share of the service sector in the economic growth, and the role of science in ensuring the competitiveness of national economies. The most appropriate definition of employment, on the basis of the purposes of our study, we believe is that offered by O. Veredyuk: "As employment we understand not only the state in which the individual has a income-generating job, but also a complex system of social and labor relations, appearing on the labor resource between the individual and society and the indirect employer. Employment, as a system of relations, affects a wide range of issues, including issues of quality of workforce and human capital investment, workplace creation, employment and working conditions, discrimination in the labor market, state regulation of these relations, and so on" (Ivanter 2011: 4).

First of all, it is necessary to distinguish between the mechanisms regulating the processes of employment in order to ensure the post-industrial modernization of the Belorussian economy in all three major economic subsystems: 
manufacturing, the service sector and science. As noted in the literature on the subject, "employment (its quantitative and qualitative characteristics) is one of the key indicators of the state of economic development (including the transition to a post-industrial stage)" (Veredyuk 2010: 37).

For the Republic of Belarus, the transition to a post-industrial economy is directly related to the problem of industrial modernization. There is preserved the surplus employment (hidden unemployment) in large industrial enterprises today, while the shortage of labor in the economy is held in country.

It should be emphasized that the purpose of modernization of the Belorussian economy should be labor-saving. The saving of social labor had always been and will be the main measure of the effectiveness of economic development. For the Republic of Belarus, the scarcest resource today is skilled labor. This is not always obvious, because in a number of companies and in some regions there is excess employment which, similarly to Russia (Ivanter 2011: 3-10), is mostly structural: for qualifications and specialties, by region, by industry, by sex and age groups. The shortage of labor of Belarus could be explained by the 1990s demographic dip.

The Russian Federation as well as the Republic of Belarus have inherited a number of problems decreasing the effectiveness of the national economy from the Soviet Union. For example, the director of the Institute of Economic Forecasting of the Russian Academy of Sciences, V. Ivanter notes in this regard: "the lack of labor resources, is more serious, when we take into account not only quantitative, but also qualitative and structural measurement. To present a problem in terms of the qualitative approach is sufficient to note that the country (Russian Federation) even now has a obvious shortage of specialists in the field of high technology production, i.e. lack of specialists capable to work in the real sector of the economy, processing industry, which impact on the depth of processing of extracted natural resources. On the other hand, a negative factor is the high labor intensity of many basic manufacturing processes, including machine building, fuel and energy complex, power industry, agriculture, transport and communications. Thus, the lack of qualified specialists and skilled workers is aggravated by workforce overspending, because of technological obsolescence of most sectors and industries of our economy" (Ivanter 2011: 4).

It is not the mistakes of the current government, but the past inheritance of the Soviet Union's large and inefficient economy. As many leading economists have noticed, the economic growth in Russia and Belarus first of all will be the 
real economic growth. V. Ivanter emphasizes: "Guess if you can become like the United States and live by servicing the huge financial flows, it is unrealistic. It should proceed from reality and pragmatic capabilities ... Therefore, without the scale labor-saving Russia will not do. Now we need to do everything possible to organize the process of the general labor and human resources saving on the basis of mainly new, high-tech industry" (Ivanter 2011: 5). Accordingly, in Belarus the successful modernization of the economy depends primarily on its ability to create a country in the modern industrial sector, i.e. move from mass production to flexible technological innovation-oriented production.

There is a purpose for Belarus today to build social and economic mechanisms of labor saving and labor-based high-tech industrial upgrading. The highly skilled and highly productive labor is the main resource for providing consistently high rates of economic growth and achieve average real incomes of Belorussians at the level of the developed EU countries.

The adoption of labor-saving as a major priority of the Belorussian economy enables us to take a fresh look at the problem of staff upgrading in terms of starting modernization. The formation of new technological structures based on the prevalence of high technologies on labor-intensity and capital-intensity is accompanied by the rapid development of information economy. The implementation of labor-saving technology (high technology) will lead to an increased demand for highly skilled workers. The inevitability of this phenomenon is becoming apparent, and the fact that without the necessary number of highly skilled workers there cannot be mass adoption of high technologies into production. In other words, the development of the new post-industrial worker and the implementation of new technologies are two sides of the same coin. Recognizing this, and the fact that in order to implement a new technology (since it has been developed) a year will do sometimes, whereas for the training of highly qualified workers who can use it effectively one needs from 5 to 10 years, it must be concluded that some approaches of higher and secondary education should be reviewed. Today, universities and educational institutions should train staff not only (and maybe not so much) at the request of companies based on existing technologies, but, for the long-term plans, on the basis of the technological modernization of the country. Accordingly, the requirements for the forecast of scientific and technical progress development must be radically changed, and not be relied on the principle of "from the achieved". The requirements should rely on real strategies of 
technological modernization of economy in the context of global technological trends.

It is common knowledge that the cause of post-industrial changes in production is technological changes: the predominance of high technologies in laborintensity and capital-intensity. An active development of high technologies in the Republic of Belarus will lead to an increased demand for highly skilled workers and a decrease in the low-skilled worker demand. However, when assessing the prospects of employment in our country, it is necessary to take into account, as rightly noted by M. Castells, that the spread of information technology does not reduce the overall level of employment (Castels 2010); although it significantly alters the structure of employment (labor force is increasingly moving into services).

The rapid development of technology requires appropriate changes in the specialization of skills, i.e. there is a problem of training and retraining. The increase in specialization of skills, in the context of rapid changes in qualification requirements, reduces the substitutability of labor. Accordingly, it is the costs increasing the replacement of intellectual labor that are higher in comparison with the costs of replacing the physical labor. Changes in production caused by technological innovations have multiple, and not always unambiguous, impact on employment. Such impact is manifested, first of all, in the changing structure of labor demand as well as in the nature of industrial relations (Toffler A., Toffler H. 1993).

In the post-Soviet period in Belarus the system of training and its structure changed. While an excessive amount of engineers graduated from USSR Universities, the opposite tendency became dominant in the post-Soviet period - universities began to produce excessive amounts of lawyers and economists thus contributing to the oversupply of specialists with higher education diplomas. There was a situation in the financial sector when many functions carried out by specialists with secondary special education were carried out by graduates from highly educational institutions. As a result, the diploma of higher education was impaired, highly qualified personnel were not effectively used, i.e. wasting social labor.

Today in Belarus there is a need to form the modern industrial (post-industrial) policy, aimed at accelerating the accumulation of human and social potential as the main components of the increased economic efficiency of the industrial technological structure. This policy should include the mechanisms of redistri- 
buting budgetary resources for rapid structural transformation of the domestic industry. In addition, it is important to strengthen the meaning of advanced technological planning for local universities' timely response to the new needs of the industrial sector, while training the specialists with higher and secondary special education. The system of continuous training for all professionals should become more flexible, and in some cases, more specialized.

In terms of transition to the postindustrial society, the role of knowledge increases, which is reflected in the change of the ratio of production factors (with knowledge and information taking the lead), and there is the transformation of added value structure (increases the share of the intellect-created value).

In the post-industrial society knowledge becomes both object and product of labor, there are significant transformations in the institutional structure of the economy. Institutions producing intangible goods (knowledge), training and research centers replacing industrial corporations - institutions of mass production of material goods - become the leader. The strengthening of the role of knowledge is accompanied by changes in the nature of work, where an increase is the creative part. Obviously, this entails the need to improve the individualization of employment contract, taking into account the displacement of the needs and values of the individual from the material toward the intangible, the adaptation of motivation due to the increased non-economic incentives to activities to further improvement of the evaluation criteria of participation of labor resources in the creation of added value (Veredyuk 2010: 40).

Today, it is important that the focus of the entire Belorussian science is the needs of the real economy (the core of the society's economic system), which requires the development of criteria so as to determine the socio-economic efficiency of imports of a particular technological innovation or the development of its domestic experts. Based on the post-Soviet Belorussian reality, it is currently impossible to stop state funding for applied research, since the National Academy of Sciences should take part in the applied research, previously engaged by industry institutes.

The tasks of the post-industrial modernization require a fundamentally different, in comparison with the existing, legal framework to ensure the advancement of science in the production. M. Myasnikovich, on this occasion, said that "there is a need of a legally enforceable right to create a venture capital and innovative companies on the principles of the joint venture company, with a most possible simple accounting and minimal tax rates, there is a need of making changes in 
labor legislation, labor costs, legislative strengthening rights to the results of R \& D" (Myasnikovich 2010: 43). Further, the author indicates that "the ownership of the R \& D results, created with the participation of the budget belong only to government customers, but implementing agencies, we believe, must have the same rights. The authors of innovative projects should be legally entitled to a fee - a percentage of the economic effect of output of innovative products or profits of the enterprise - to choose from" (Myasnikovich 2010: 43).

Talking about the new role of the services sector in post-industrial society, including the growth in this sector of the generated GDP, increasing the number of employees, etc., it should be taken into account that more than half of the positions associated with the services (engineers, technicians programmers and others working in the industry), in fact, belong to the secondary sector of the economy (Gershuny 1978). It should also be borne in mind that, "the trend towards the economic development of self-service (self-service economy)," says O. Veredyuk, "involving the use of technical household goods (cars, washing machines, home theater and so on) instead of acquiring the relevant services in the market, leads to a reduction in workplaces in the service sector" (Veredyuk 2010: 37). G. Espin-Andersen has noted that in a post-industrial economy there is a marked decline in the growth of standard and flexible forms of employment (part/full time, and so on), as well as the feminization of male labor (Changing Classes: Stratification and Mobility in Post-Industrial Societies 1993).

Thus, it should be recognized that the precise quantification of changes in the services sector employment today is difficult. However, the relative increase in employment in the services sector is an important attribute of the transition to postindustrial society. Such a change in the structure of employment rises, in the Belorussian context, a number of practical problems associated with the complexity of adaptation of redundant workers in material production to the requirements of the sphere of immaterial production.

The global institutional crisis of 2008-2012 opening the era of modern capitalism collapse and inevitably leading to the increase in international controversy generated by the selfishness of the "golden billion" and the reluctance of most people in the world to put up with the modern forms of capitalist (predatory in nature) redistribution of material, intellectual and cultural values, allows a high degree of probability to model the future society (including its economic system) in the event of a favorable (non-catastrophic) version of the human civilization 
development. In this case, the future of a society that has managed to overcome the defects of classical capitalism will be characterized by the following features:

- multistructuralism, with the transition of private capitalist structure from dominant to the peripheral, while maintaining its high entrepreneurial potential as an important factor of social reproduction,

- morality, i.e. the extension of morality as the most important criterion and factor in the formation and development of the international political and economic relations and national economies,

- environmentally friendly attitude, i.e. the strengthening of environmental imperative in the process of social reproduction,

- over tech, embodied in the formation of the 5-6th technologically-structured real economy.

Thus, the transition of economy to a "post-capitalist" stage of development cannot be accompanied by the emergence of a new form of social organization - post-capitalist socio-scientific society. This definition emphasizes, on the one hand, an increase in the moral and environmental (post-capitalist) principles for evaluating the cost-effectiveness of social reproduction. On the other hand, it shows an increase in the role of the scientific and technological revolution and new institutional forms of use of its achievements in the economic system of society (the formation of the social and scientific community).

It should be emphasized that, in the economic literature, when considering the post-industrial economy, very little attention is paid to the establishment of such an important institution, personifying the process of turning science into a direct productive force, as a social-scientific community. This is not only because many economists have stood on the positions of economic imperialism, focused either on the virtual problems of functioning of an ideal market economy, or on local aspects of certain markets, but also because these problems require political and economic methods of investigation, now owned by a few scientists and economists. However, without understanding, as a socio-scientific community, the political and economic nature of such a complex institutional phenomenon, it is impossible to unlock the full social and economic impact of scientific and technological revolution.

Most of foreign researchers, talking about the future (post-apocalyptic, postindustrial, post-entrepreneurial, etc.) community, primarily examines the progress of theoretical knowledge. With the advent of a class of intellectuals and higher economic return from their labor, a trend towards the separation of means of pro- 
duction from the worker has been replaced by the opposite - their merger. Thus both parties (employees and employers) are neither dependent, nor independent but rather interdependent, and that radically changes the form of management.

The class of intellectuals is a gain for the new post-capitalist motivational system in that it offers their moral attitudes. Morality, a social capital accumulated at all levels of society, ensures the sustainable development, national security and high competitiveness of domestic products. As the class of intellectuals develops and increases its social and economic role in society, its non-materialistic motivation, characteristic begins to penetrate from the informational structure into other economic structures. The latter in in itself also contributes to the increase in the value of morality in economic activity.

M. Izmailova rightly notes that "the institutional structure of a modern society seems to its researchers consisting of six elements: economic enterprises, the social complex, academic institutions, enterprises for the production of public goods, voluntary organizations and households. The first four elements constitute the formal economy, while the last two - complementary economy" (Izmailova 2008: 39). In the post-capitalist socio-scientific community research institutes and universities engaged in the checking, systematization and formation of new fundamentals, theoretical knowledge becomes the dominant technological structure. This does not mean, as M. Ismailova has emphasized, that the majority of "the citizens of post-industrial society (post-capitalist socio-scientific community) will be presented by scientists, engineers, technicians and intellectuals, even though today the majority of the population is not a businessman; rather it draws attention to the constructive role played by science as commercial in nature, the company in the transition to the new system" (Izmailova 2008: 39).

Thus, the institutional implications for the technological modernization of Belarus, in the case the country will move in line with global technological and civilizational trends, will be:

1. Firstly, the formation of an efficient informational economic structure that will long enough remain peripheral. In terms of this structure there will be formed the future post-capitalist institutions, social and scientific community. At the same time, a number of institutions today are mature enough or could soon become such (for example, the Institute of Intellectual Property). However, most of these institutions are functioning mainly in the information technological structure. 
2. Secondly, the further transformation of the institutional Belorussian economic model in the direction of increasing the autonomy of economic entities, as a response to the complexity under the influence of the latest scientific achievements of the process of social reproduction. This will reinforce social, environmental, economic morality of society as well as increase labor mobility.

3. Thirdly, the formation of a modern industrial policy as the most important component of increasing the economic efficiency of industrial technological structure, at present dominant in the economic sphere of Belarus.

4. Fourthly, because after the recovery from the global financial crisis, the world economy will face the increasing cross-country competition largely predetermined by the transition to the next technological cycle, the advantage will go to those countries that have created the post-capitalist social and scientific community with the most appropriate institutions. At the same time the countries with the municipal material and technological environment have a historic chance to become world technological and economic leaders, as post-capitalist (i.e. humanistic, social), collective, public, universal moral values are more inherent to the population of these countries. The majority of the inhabitants of the non-communal material and technological environment which includes all the countries "of Protestant fundamentalism" or the "golden billion", including their intellectuals, are focused on the dominance of individualistic motivations. It is noticeable by the accents of western researchers, describing the symptoms of the class attribute of intellectuals in the "post-capitalist" society. The population of the Republic of Belarus and many other post-Soviet countries, despite the ideological speculation on the public sense of collectivism in the Soviet period and the development of private capitalist structure today, is still following its collectivist mass-guided universal moral values. All this enables the country to evolve faster, institutionally, towards the formation of institutions of the post-capitalist socio-scientific community so as to find the replacement of obsolete social and economic institutions quickly, to capitalize the resources needed for emergencies, to carry out socialization and moralization of economic practice. On this basis, the Republic of Belarus, along with the BRIC countries, may, in the foreseeable future, at the stage of the global change of technological structures, reach the world's technological and economic leaders. 


\section{Summary}

The article defines the basic principles of the socio-scientific community in the process of modernization of the Belorussian economy as well as it justifies the necessity of forming the effective economic structure information for the development of the social and scientific community.

\section{References}

Bell D., The Coming of Post-Industrial Society: A Venture in Social Forecasting, New York, Basic Books, 1973.

Brzezinski Z., Between Two Ages, New York, 1970.

Castells M., The Information Age: Economy, Society and Culture. Vol. I: The Rise of the Network Society, London and Oxford, Blackwell Publisher, 1996.

Castells M., The Rise of the Network Society: 2nd ed., Wiley-Blackwell, 2010.

Changing Classes: Stratification and Mobility in Post-Industrial Societies, Esping-Andersen G. SAGE Publications, 1993.

Gershuny J., After Industrial Society? The Emerging Self-Service Economy, Macmillan, 1978.

Inozemtsev V., Beyond Economic Society, Moscow, Academia-Science, 1998.

Ivanter V., Labor-Saving as a Priority, "The Economist" 2011, No. 1.

Izmailova M., Socio-Economic Consequences of the Post-Industrial Stage of Development of the Society, Bulletin of the Russian State Trade and Economic University, 2008, No. 6 (27).

Machlup F., The Production and Distribution of Knowledge in the United States, Princeton University Press, 1962.

Myasnikovich M., About the Conceptual Directions Providing the Innovative Growth of the Republic of Belarus in the Medium Term, Economic Bulletin of the INAH of the Ministry of Economy of the Republic of Belarus, 2010, No.12.

Roszak T., Where the Wasteland Ends: Politics and Transcendence in Postindustrial Society, 1972.

Solodovnikov S., Socio-Class Structure of Belarus, Russia and Ukraine, Grodno, 2011.

Solodovnikov S., Socio-Economic Determination Systems, Minsk, 2002.

Solodovnikov S., The Transformation of the Socio-Class Structure of the Belarusian Community: Methodology, Theory, Practice, Minsk, Law and Economics, 2003.

The Knowledge Society, Holland, 1984. 